\title{
Uji Toksisitas Kubis Bunga Diolah Minimal (KBDM) Hasil Ozonasi
}

\section{The Toxicity Test of Cauliflower (Brassica oleracea L.) with Minimally Processed by Ozonation}

Imas Siti Setiasih, In-In Hanidah, Dwi Wahyuda Wira, Tita Rialita, Debby M. Sumanti

Staf Teknologi Pangan, Fakultas teknologi Industri Pertanian, Universitas Padjadjaran Jl. Raya Bandung - Sumedang KM.21, Jatinangor, Indonesia

*email: iimdarajat@yahoo.com

\begin{tabular}{l} 
A R T I C L E IN F O \\
\hline Article history \\
Received: 27 Juni 2016 \\
Accepted: 15 Juli 2016 \\
Available online: Februari 2017 \\
\hline Keywords : \\
ozonation TIP-01 \\
minimally processed \\
cauliflower \\
acute toxicity \\
sub -chronic toxicity \\
rats \\
\hline Kata kunci : \\
Ozonasi TIP-01 \\
Kubis bunga diolah minimal \\
Tosisitas akut \\
Toksisitas subkronis \\
Tikus putih
\end{tabular}

\begin{abstract}
A B STR A C T
One of attempt to extend the shelf life with processed cauliflower minimally by used a solution 1.9 ppm of ozone. In the washing process, using ozonation TIP-01 tool that has the ability to reduce total mikroorgnisme amounted to $46.30 \%$. and pesticides amounting to 59.93\%. The applied of ozone to food will be broken down quickly and leaves no residue. The study aims to determine the acute toxicity of Cauliflower (Brassica oleracea L.) with minimally processed by ozonation in rats, followed by sub-chronic toxicity tests against liver and kidney function experimental animals. The method is carried acute and sub-chronic toxicity test using white Wistar rats. Acute toxicity tests performed at a dose of $15,000 \mathrm{mg} / \mathrm{kg}$, while the sub-chronic toxicity test performed on multilevel dose is: $1000 \mathrm{mg} / \mathrm{kg}$, $10,000 \mathrm{mg} / \mathrm{kg} \mathrm{bw}$ and 20,000 $\mathrm{mg} / \mathrm{kg} \mathrm{bw}$. The results show that ozonation does not interfere with the results KBDM animal health. This berdasarakan acute toxicity values (LD50) is zero or no experimental animals that die on the dose and sub-chronic toxicity test on the liver and kidneys of animals trying to cause degeneration of the light that is reversible
\end{abstract}

\begin{abstract}
A B S T R A K
Salah satu usaha untuk memperpanjang umur simpan kubis bunga diolah minimum(KBDM) yaitu dengan proses pencucian mengunakan larutan ozon 1,9 ppm. Dalam proses pencucian tersebut,menggunakan alat Ozonasi TIP-01 yang memiliki kemampuan mereduksi total mikroorgnisme sebesar 46,30\%. dan pestisida sebesar 59,93\%. Ozon jika diaplikasikan pada makanan akan diuraikan dengan cepat serta tidak meninggalkan residu. Penelitian bertujuan untuk mengetahui toksisitas akut dari KBDM hasil ozonasi pada hewan coba tikus yang dilanjutkan dengan uji toksisitas sub kronis terhadap fungsi organ hati dan ginjal hewan coba. Metode yang dilakukan uji toksisitas akut dan subkronis menggunakan tikus putih dengan galur Wistar. Uji toksisitas akut dilakukan pada dosis $15.000 \mathrm{mg} / \mathrm{kgbb}$, sedangkan uji toksisitas subkronis dilakukan pada dosis bertingkat yaitu: $1000 \mathrm{mg} / \mathrm{kgbb}, 10.000 \mathrm{mg} / \mathrm{kg}$ bb dan $20.000 \mathrm{mg} / \mathrm{kg}$ bb. Hasil penelitian menunjukkan bahwa KBDM hasil ozonasi tidak mengganggu kesehatan hewan coba. Hal ini berdasarakan nilai toksisitas akut $\left(\mathrm{LD}_{50}\right)$ adalah Nol atau tidak ada hewan coba yang mati pada dosis tersebut dan uji toksisitas subkronis pada hati dan ginjal hewan coba menimbulkan degenerasi ringan yang bersifat reversible
\end{abstract}

\section{Pendahuluan}

Keamanan pangan merupakan kondisi dan upaya yang diperlukan untuk mencegah pangan terhindar dari kemungkinan terkena cemaran biologis, kimia dan benda asing yang dapat mengganggu, merugikan, dan membahayakan kesehatan manusia. Bahaya biologis adalah bahaya yang berupa cemaran mikroba dan parasit yang dapat menyebabkan keracunan atau penyakit. Bahaya biologis dapat berasal dari udara, tanah, air dan tempat lainnya yang kotor. Bahaya kimia merupakan bahaya yang berupa cemaran bahan kimia beracun yang dapat menyebabkan keracunan atau penyakit. Salah senyawa kimia dalam bentuk gas yang dapat digunakan sebagai antimikroba dan dekontaminasi adalah ozon.

Ozon merupakan oksidator kuat yang dapat dimanfaatkan untuk membunuh bakteri (sterilization), menghilangkan warna (decoloration), menghilangkan bau (deodoration) dan menguraikan senyawa organik 
(degradation). Gas ozon jika diaplikasikan untuk makanan akan diuraikan dengan cepat serta tidak meninggalkan residu. Menurut Khadre et al. (2001), gas ozon dapat digunakan untuk dekontaminasi produk, peralatan, permukaan makanan dan lingkungan pengolahan. Penerapan ozon atau ozonasi pada makanan perlu peninjauan keamanannya. Salah satu pengujian keamanan makanan adalah uji toksisitas.

Uji toksisitas merupakan salah satu pengujian yang dilakukan untuk menilai keamanan suatu senyawa kimia baik senyawa itu sendiri maupun senyawa tersebut berada dalam bahan-bahan lainnya seperti bahan pangan. Menurut Lu (1995), toksisitas didefenisikan sebagai kajian tentang hakikat dan mekanisme efek toksik berbagai bahan terhadap makhluk hidup dan sistem biologi lainnya. Mekanisme kerja yang mendasari efek toksik biasanya dapat diketahui lewat berbagai perubahan tingkat subseluler. Bagian yang potensial dipengaruhi toksikan adalah nukleulus, mitokondria, lisozom, reticulum endoplasma, struktur subseluler lainnya dan membrane plasma. Mekanisme ini juga bisa diklasifikasikan berdasarkan sifat kimia berbagai molekul sasaran berupa protein, koenzim lipid dan asam-asam nukleat. Dilain pihak karbohidrat jarang terpengaruh oleh toksikan (Nugroho, 1995).

Metode uji toksisitas dapat dibedakan menjadi dua golongan, yaitu uji toksisitas yang dirancang untuk mengetahui atau mengevaluasi efek umum suatu senya dan uji toksisitas yang dirancang untuk mengevaluasi secara rinci tipe toksisitas spesifik (Hayes 2001, Loomis 1996, Lu 1995). Uji toksisitas umum meliputi: uji toksisitas aku, uji toksisitas subkronis dan uji toksisitas kronis. Sedangkan uji toksisitas spesifik meliputi:uji teratogenitas, uji mutagenitas, uji karsinogenitas.

Uji toksisitas subkronis dilakukan untuk mengevaluasi efek senyawa apabila apabila diberikan kepada hewan uji secara berulang-ulang. Biasanya diberika senya $10 \%$ dari masa hidup hewan, yaitu 3 bulan untuk tikus dan 1-2 tahun untuk anjing. Uji toksisitas subkronis menyakut evaluasi seluruh hewan untuk mengetahui efek patologi anatomi dan histology. Uji ini dapat menghasilkan informasi toksisitas zat uji yang berkaitan dengan organ sasaran, efek organ tersebut, dan hubungan dosis efek dan dosis respon. Informasi tersebut dapat member petunjuk untuk memnrtukan jenis pengujian yang lainnya.

Penelitian bertujuan untuk mengetahui toksisitas akut dan sub kronis dari KBDM hasil ozonasi pada hewan pcoba tikus terhadap fungsi organ hati dan ginjal hewan coba.

\section{Metode Penelitian}

Pengujian toksisitas akut dari kubis bunga fresh-cut yang diberi perlakuan ozon pada hewan coba tikus dilanjutkan dengan uji toksisitas sub kronis kubis bunga fresh-cut terhadap fungsi organ hati dan ginjal hewan percobaan.

Hewan Uji yang digunakan adalah tikus putih jantan dan betina galur wistar dengan berat 100-200 gram, usia 2-3 bulan. Sebelum pengujian dimulai hewan uji harus diadaptasikan selama tujuh hari. Diamati perilaku hewan sehingga tidak ada hewan yang sakit dan tidak terjadi penurunan bobot hewan coba sebanyak 10 $\%$.

Bahan Uji yang digunakan adalah kubis bunga fresh-cut yang sudah diozon dan air suling. Uji toksisitas akut diawali dengan memberikan bahan uji secara oral ke hewan coba tikus pada dosis $15.000 \mathrm{mg} / \mathrm{kgbb}$, kemudian diamati efek pemberian KBDM pada menit ke-30, 60, dan 120, meliputi aktivitas motorik, fenomena straub, piloereksi, ptosis, midriasis, grooming, urinasi, defekasi dan salivasi. Setelah 24 jam, data tikus yang mati dicatat. Tikus yang bertahan hidup diamati sampai hari ke-14.. Sedangkan Uji toksisitas sub kronis dibagi menjadi 4 kelompok dosis, 3 kelompok uji dan 1 kelompok kontrol. $\mathrm{K} 1$ pemberian dosis $1000 \mathrm{mg} / \mathrm{kg}$ bb sayur berozon (dosis rendah ), K2 pemberian dosis $10000 \mathrm{mg} / \mathrm{kgbb}$ sayur berozon (dosis tengah), K3 pemberian dosis 20000 $\mathrm{mg} / \mathrm{kgbb}$ sayur berozon (dosis atas), K4 merupakan satelit kontrol (aquades), K5 merupakan satelit dosis 20000 $\mathrm{mg} / \mathrm{kg}$ bb (satelit dosis atas). Kode $\mathrm{K}$ untuk tikus jantan dan kode L untuk tikus betina merupakan. Pengamatan dilakukan setiap hari selama 90 hari. Kelompok satelit tetap dipelihara selama 120 hari tanpa diberikan bahan. Evaluasi hasil uji dilakukan melalui pengamatan pasca mati terhadap organ-organ hewan coba untuk mengamati perubahan patologi anatomi dan histopatologinya.

\section{Hasil dan Pembahasan \\ Uji Toksisitas Akut}

Uji toksisitas akut adalah uji yang dilakukan untuk mengukur derajat efek suatu senyawa yang diberikan pada hewan coba tertentu dan pengamatannya dilakukan selama 24 jam pertama dalam satu kesempatan (Loomis, 1996). Pengujian toksisitas dilakukan dengan pengamatan prilaku hewan coba dan presentase kematian selama 24 jam. Hasil presentase kematian hewan coba disajikan pada Tabel 1.

Tabel 1. Presentase Mortalitas Kumulatif Hewan Coba Setelah pemberian KBDM

\begin{tabular}{ccccccc}
\hline \multirow{2}{*}{ Perlakuan } & \multicolumn{6}{c}{ Jumlah Mortalitas Kumulatis Hewan Coba (\%) } \\
\cline { 2 - 7 } & 0 jam & $\begin{array}{c}0,5 \\
\text { jam }\end{array}$ & $\begin{array}{c}\text { jam } \\
\text { jam }\end{array}$ & $\begin{array}{c}\text { jam } \\
\text { jam }\end{array}$ & $\begin{array}{c}\text { jam } \\
\text { jam }\end{array}$ \\
\hline Kontrol & 0 & 0 & 0 & 0 & 0 & 0 \\
15000 & 0 & 0 & 0 & 0 & 0 & 0 \\
$\mathrm{mg} / \mathrm{kg} \mathrm{bb}$ & 0 & 0 & &
\end{tabular}

Dari hasil pengujian, ternyata tidak tejadi kematian hewan coba pada dosis $15000 \mathrm{mg} / \mathrm{kg}$ bb begitu juga pada kontrol sehingga KBDM berozon tidak mempunyai $\mathrm{LD}_{50}$ atau dapat dikatakan non toksik. Menurut Lu (1995), apabila $\mathrm{LD}_{50}$ besar dari $15000 \mathrm{mg} / \mathrm{kg}$ bb maka senyawa tersebut masuk kedalam tingkat keracunan praktis non toksik (practically non toxic). Secara umum, semakin kecil nlai $\mathrm{LD}_{50}$, semakin toksik senyawa tersebut dan semakin besar nilai $\mathrm{LD}_{50}$ semakin rendah toksisitasnya (Loomis, 1996). Untuk mengetahui efek terhadap 
kesehatan individu dapat dilihat dari kondisi darah dengan cara pengujian hematologi darah hewan coba yang diberi KBDM berozon. Hasil pengujian hematologi darah hewan uji disajikan pada Tabel2.

Dari tabel tersebut terlihat bahwa berdasarkan parameter yang diuji yaitu kadar hemoglobin, hematokrit, leukocit, eritrosit, dan trombosit darah hewan coba yang diberi kubis bunga fresh cut berozon masih dibawah kontrol negatif dan berada didalam jumlah kisaran standar. Hasil penelitian (Tabel 2) menunjukkan bahwa ozonasi KBDM konsentrasi 1,9 ppm selama 5 menit tidak mengganggu kesehatan hewan coba, sehingga aman untuk dikonsumsi manusia.

Tabel 2. Hasil Pengujian Hematologi Darah Hewan Coba

\begin{tabular}{|c|c|c|c|c|}
\hline Parameter Hematologi & Kontrol Negatif & Perlakuan & Standar & Satuan \\
\hline Hemoglobin & 14.7 & 14.42 & $12-17.5^{* * * * *}$ & $\mathrm{~g} / \mathrm{dL}$ \\
\hline Hematokrit & 52.5 & 49.2 & $39-53^{* * *}$ & $\%$ \\
\hline Leukosit & 9850 & 9400 & $6600-12600^{*}$ & $/ \mathrm{mm} 3$ \\
\hline Eritrosit & 7.75 & 6.921 & $7.2-9.6 * *$ & juta/uL \\
\hline Trombosit & 1070500 & 763000 & $1240000(1100000-1380000)$ & $/ \mathrm{mm} 3$ \\
\hline \multicolumn{5}{|l|}{ Indek Eritrosit } \\
\hline $\mathrm{MCV}$ & 71.1 & 71.91 & & \\
\hline $\mathrm{MCH}$ & 20.05 & 21.35 & & \\
\hline $\mathrm{MCHC}$ & 26.7 & 29.59 & & \\
\hline Laju Endap darah & 1 & 1 & & $\mathrm{~mm} / \mathrm{jam}$ \\
\hline
\end{tabular}

\section{Toksisitas}

$\frac{\text { Subkronis }}{\text { Pengat }}$

Pengamatan dilakukan pada organ hati dan ginjal tikus putih jantan dan betina terutama pada hepatosit, sinusoid, dan ada tidaknya sel-sel radang untuk organ hati. Untuk ginjal dilakukan pada nephron, tubulus dan interstitium. Perubahan yang terjadi pada kontrol negatif (K1 dan L1) terjadi degenerasi hidropis ringan tetapi hati masih membetuk lobulasi yang jelas dengan vena sentralis yang berada di tengah. Sitoplasma mengambil warna merah muda dan inti sel mengambil warna unggu kebiruan.

Pada kelompok Perlakuan K2, K3, K4, L2, L3, L4 hepatosit masih tersusun relative normal tapi ditemukannya degenerasi hidropis pada K2 dan L2 ditunjukkan dengan terdesaknya intisel hepatosit kearah pinggir oleh cairan sitoplasma sel. Sedangkan pada K3 dan K4, L2 dan L3 terjadi nekrosis sel-sel hati. Terjadinya oedema pada organ hati, ditunjukan dengan semakin lebarnya sinusoid-sinosoid hati. Pada Kelompok perlakuan K5 hati kembali menunjukkan kondisi ogan hati yang normal tetapi terdapat infiltrasi sel-sel radang.

Pengamatan pada organ ginjal tikus putih jantan dan betina pada kontrol negatif (K1 dan L1) dan kelompok perlakuan (K2, K3, K4, K5, L2, L3, L4, L5) ditemukan adanya sarang radang, degenerasi ringan pada sel tubuli dan nefron yang disebut "cludy swelling"dan terjadinya nekrose pada sel tubuli ginjal. Perubahan pada organ hati dan ginjal tikus putih jantan dapat dilihat pada Gambar 1.

Hasil pengamatan histopatologi hati dan ginjal kemudian diskoring dan didapatkan nilai berdasarkan hasil skoring tersebut. Kemudian nilai tersebut diuji statistik dan dilanjutkan dengan $t$ tes yang disajikan pada Tabel 3. Perlakuan K dan L merupakan dosis satelit yang menentukan apakah pemberian kubis bunga berozon berpengaruh atau tidak kepada organ hati dan ginjal. Berdasarkan pengujian statistik bahwa tidak terjadi perubahan pada organ hati dan organ ginjal baik antar kontrol negatif dan antara perlakuan itu sendiri.

Degenerasi hidropik atau degenerasi vakuoler dapat dilihat secara mikrosopis dengan ditemukannya vakuola yang jernih tersebar dalam sitoplasma, kadang vakuola yang kecil bersatu membentuk vakuola lebih besar sehingga inti sel terdesak ke pinggir. Degenerasi hidropik (edema intraseluler lebih mencolok daripada bengkak keruh. Pembengkakkan tidak hanya terjadi pada endoplasmic reticulum dan mitochondria tetapi air juga mengumpul dalam rongga-ronga sel. Kemunduran sering terjadi pada sel hati akibat racun-racun tetrachloride atau chloroform (Saleh 1996). Menurut Cheville (2006), degenerasi hidropik merupakan suatu kerusakan sel yang revesibel yang diakibatkan terganggunya permiabilitas membrane sel hepatosit. Kondisi tersebut menyebabkan ion $\mathrm{K}^{+}$mudah keluar dari sel dan sebaliknya $\mathrm{Ca}^{+}, \mathrm{Na}^{+}$ serta air mudah masuk kedalam sel dan mengakibatkan terjadinya pembengkakan.

Tabel 3. Hasil Uji Sidik Ragam Histopatologi Hati dan Ginjal Tikus Putih Jantan dan Betina

\begin{tabular}{ccc}
\hline \multirow{2}{*}{ Perlakuan } & \multicolumn{2}{c}{ Pengamatan } \\
\cline { 2 - 3 } & Hati & Ginjal \\
\hline K 1 & $1.57 \mathrm{a}$ & $2.83 \mathrm{a}$ \\
K 2 & $1.50 \mathrm{a}$ & $2.37 \mathrm{a}$ \\
K 3 & $1.63 \mathrm{a}$ & $2.60 \mathrm{a}$ \\
K 4 & $1.27 \mathrm{a}$ & $2.00 \mathrm{a}$ \\
K 5 & $1.37 \mathrm{a}$ & $1.13 \mathrm{a}$ \\
L 1 & $1.07 \mathrm{a}$ & $1.60 \mathrm{a}$ \\
L 2 & $1.40 \mathrm{a}$ & $2.80 \mathrm{a}$ \\
L 3 & $3.83 \mathrm{a}$ & $3.43 \mathrm{a}$ \\
L 4 & $3.13 \mathrm{a}$ & $3.13 \mathrm{a}$ \\
L 5 & $0.80 \mathrm{a}$ & $1.93 \mathrm{a}$ \\
\hline
\end{tabular}

Keterangan: angka yang diikuti dengan huruf yang sama kearah vertical menunjukkan nilai tidak berbeda nyata $(\mathrm{P}$ $>0.05)$ 
Pada hepatosit terjadi nekrosa, kemungkinan disebabkan oleh hasil metabolism hati yaitu amoniak. Darmawam (1990) menyatakan bahwa hati mempunyai fungsi metabolic putih telur tau protein sehingga menghasilkan amoniak, asam keton, NH2 yang bersifat toksik. Pada hati dan ginjal ditemukan juga sel-sel radang, sel sel radang mungkin mungkin disabkan oleh adanya infeksi alamiah . Pada hati terjadi edema, edema adalah meningkatnya volume cairan ekstraseluler dan ekstravaskuler disertai dengan penimbunan cairan dalam sela-sela raingan dan rongga serosa, Himawan(1996).
Degenerasi bengkak keruh (cloudy swelling, degenerasi albumin) merupakan perubahan kemunduran akibat jejas yang tidak jelas. Perubahan ini ditandai oleh adanya sel-sel yang membengkaak disertai sitoplasma yang bergranul sehingga jaringan tampak keruh. Perubahan ini biasanya terjadi pada sel tubulus ginjal, sel hati sel oto jantung. Dapat terjadi akibat infeksi, demam, suhu rendah atau tinggi, anoreksia, gangguan sirkulasi, kemunduran ini bersifat reversible.

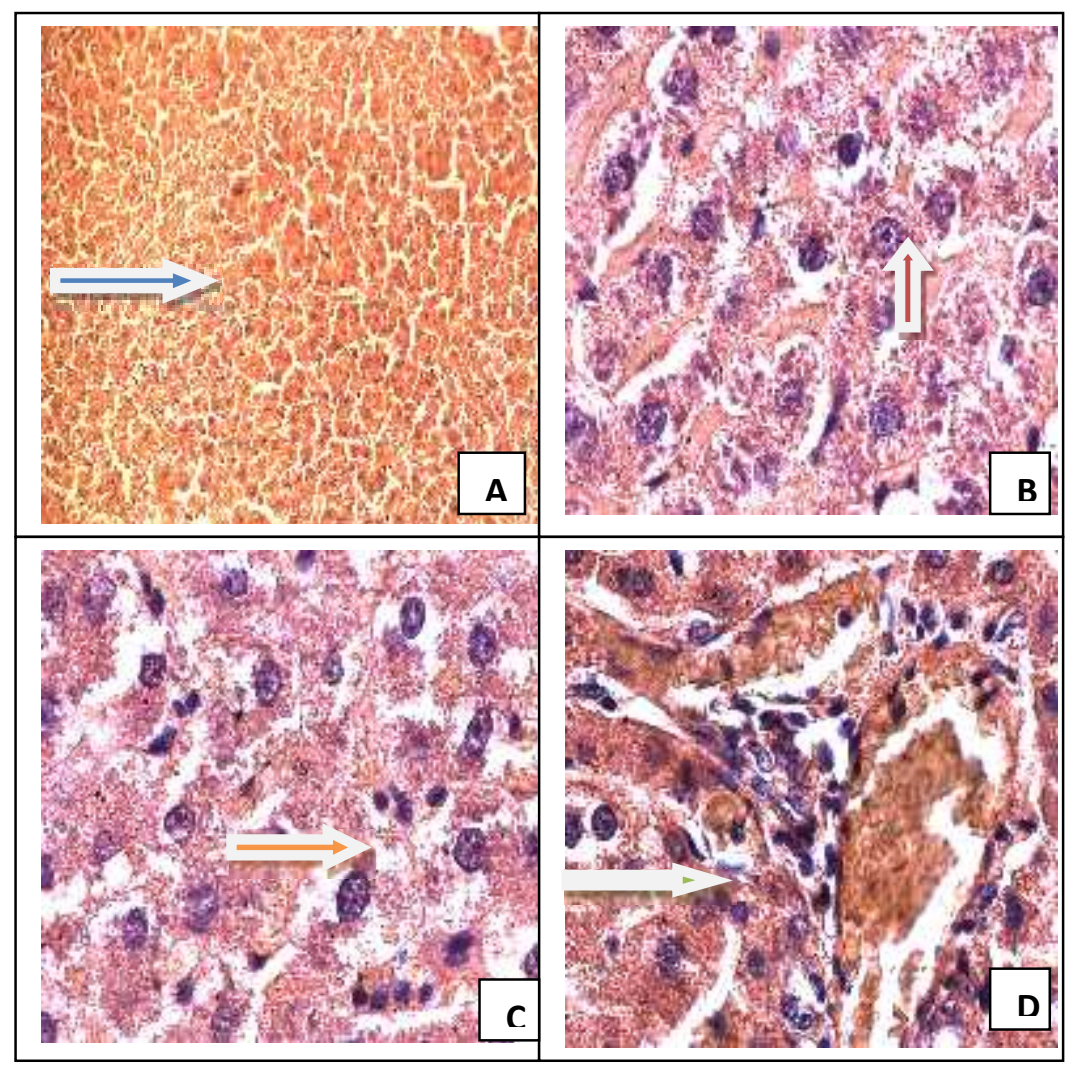

Gambar 1. Perubahan pada Organ Hati

Keterangan:

$\mathrm{A}=\mathrm{K} 4$ Oedema, sinusoid hati melebar 200x

$\mathrm{B}=\mathrm{K} 1$ Hepatosit Normal dan sinusoid hati normal 1000x

$\mathrm{C}=\mathrm{K} 2$ Hepatosit yang mengalami degenerasi hidropik 1000x

$\mathrm{D}=\mathrm{K} 5$ Sel-sel radang, $1000 \mathrm{x}$ pada tikus putih jantan 


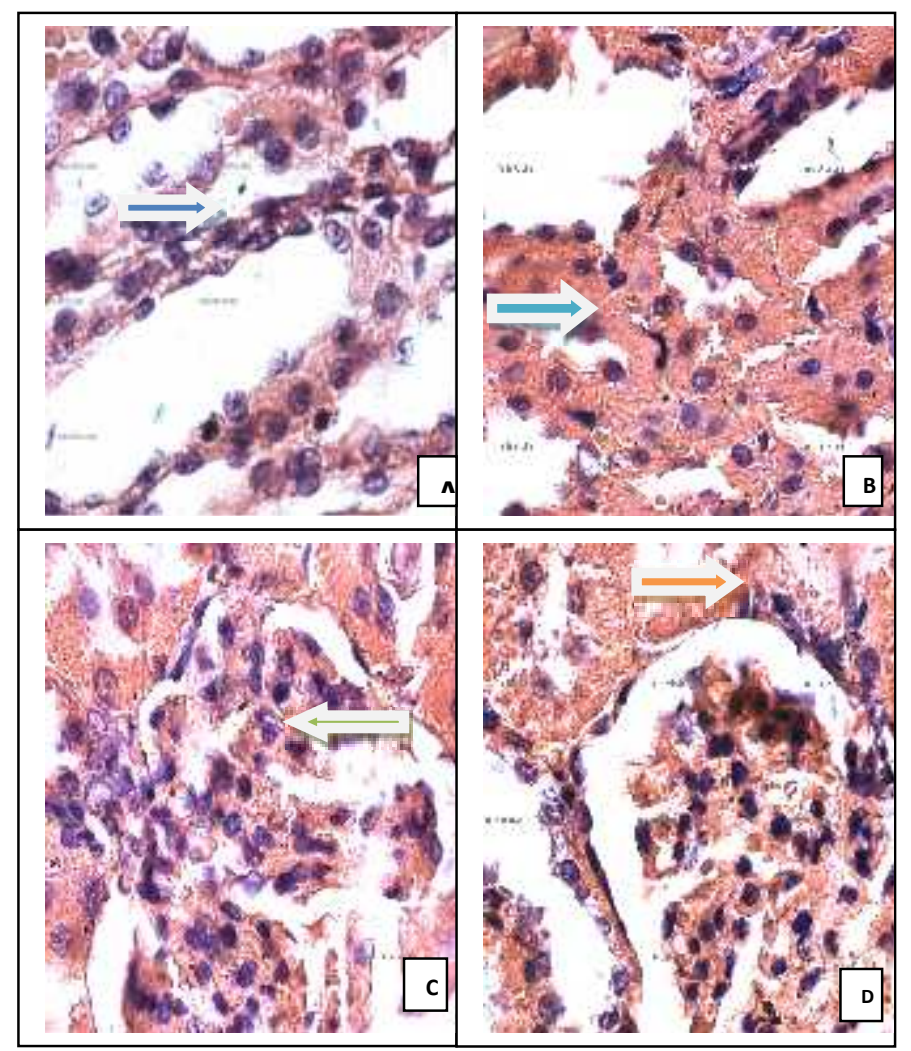

Gambar 2. Perubahan pada Organ Ganjil

Keterangan:

A dan B Degenerasi bengkak keruh (claudy swelling);

$\mathrm{C}$ dan D Infiltrasi sel-sel radang 1000xpada ginjal tikus putih jantan

\section{Kesimpulan}

Pencucian ozonasi 1,9 ppm selama 5 menit pada KBDM berdasarkan nilai $\mathrm{LD}_{50}$ tidak mengganggu kesehatan hewan uji sehingga aman untuk dikonsumsi manusia. Sedangkan berdasarkan hasil uji toksisitas subkronis pencucian ozonasi tersebut dapat menimbulkan degenerasi ringan pada hati dan ginjal tetapi degenerasi tersebut bersifat reversible (mampu kembali ke kekeadaan semula).

\section{Ucapan Terimakasih}

Ucapan terimakasih dan penghargaan yang tak terhingga disampaikan kepada Dikti yang telah memberi hibah penelitian Stranas selama 2 tahun.

\section{Pustaka}

Cheville, N. F. 2006. Introduction to Veterinary Pathology. Iowa (US). Blackwell Publishing

Himawan S. 1996. Patologi. Himawan: Bagian Patologi Anatomi Fakultas Kedokteran Universitas Indonesia. Jakarta. Bagian kedua.

Khadre, M., Yousef, A.-E., dan Kim, J.-G. 2001. Microbilogical Aspect of Ozone Aplication in Food. Food Science 66, 12442-1252.

Lu, F.C. 1995. Toksikologi Dasar:Organ, Sasaran, dan Penilaian Resiko. Ed ke-2. Universitas Indonesia Press. Jakarta.

Loomis, T.A. W.Hayes, 1987. Essential of Toxicology. 4rd. Academic Press. California.

Saleh S. 1996. Patologi, Himawan Bagian Patologi Anantomi Fakultas Kedokteran Universitas Indonesia. Jakarta. Bagian Pertama. Kelainan Retrogresif dan Progresif. 